\title{
Reducing Atmosphere Packaging Technique for Extending the Shelf-life of Food Products
}

\author{
Duried ALWAZEER ${ }^{1 *}$
}

\begin{abstract}
Food processors generally apply different techniques to extend the shelf-life of food products according to the characteristics of the product. Modified Atmosphere Packaging (MAP) uses different gases in specific combinations to replace the air surrounding the product, which leads to minimize the undesirable oxidation reactions and microbial spoilage growth permitting extending the shelf-life of the product. The property of the Reducing Atmosphere Packaging (RAP) technique is the use of reducing gas like hydrogen besides other gases such as nitrogen, argon and carbon dioxide. The advantage of the presence of a reducing gas in the gaseous combination is the prevention of the oxidation reactions such as the formation of free radicals, the deterioration of vitamins such as $\mathrm{C}, \mathrm{E}$ and beta-carotene, the deterioration of pigments such as carotenoids and the formation of off-flavors like the rancidity products. The prevention of the latter undesirable reactions aides to protect the freshness notes of the food products by preserving its natural color, taste and aroma, as well as the protection of the nutritional quality. The literature contains a few researches concerning the application of RAP on different food products. This is the first review reporting the potential application of hydrogen in modified atmosphere technology for extending the shelf-life of food products.
\end{abstract}

Keywords: Reducing Atmosphere Packaging, Food Products, Shelf-life, Nutritional Properties, Sensorial Properties

\section{Gıda Ürünlerinin Raf Ömrünün Uzatılmasına Yönelik İndirgen Atmosfer Paketleme Tekniği}

ÖZET: Gıda üreticileri, özelliklerine uygun şekilde gıda ürünlerinin raf ömrünü uzatmak amacıyla farklı teknikler uygulamaktadır. Modifiye Atmosfer Paketleme (MAP), ürünü çevreleyen hava yerine spesifik kombinasyonlara sahip farklı gazları kullanmakta, böylelikle istenmeyen oksidasyon reaksiyonlarını ve bozucu mikrobiyal gelişimi minimize ederek ürünün raf ömrünü uzatmaktadır. İndirgen Atmosfer paketleme (RAP) tekniği, azot, argon ve karbondioksit gibi gazların yanısıra hidrojen gibi indirgen bir gazın kullanımına dayanmaktadır. Gaz kombinasyonunda indirgen bir gazın varlığının sağladığı avantaj, serbest radikal oluşumu; C ve E vitaminleri gibi vitaminler ile beta-karotenin zarar görmesi; karotenoidler gibi pigmentlerin bozulması ve ransidite ürünleri gibi lezzet kaybına sebep olan ürünlerin oluşumunu önlemesidir. En son bahsi geçen istenmeyen reaksiyonların önlenmesi; ürünün besinsel kalitesinin yanı sıra doğal renk, tat ve aromasının da muhafaza edilmesiyle gıda ürünlerinin tazelik kriteri olan özelliklerini korumaya yardımcı olmaktadır. Literatürde RAP tekniğinin farklı gıda ürünlerinde uygulanmasıyla ilgili birkaç araştırma yer almaktadır. Bu çalışma, gıda ürünlerinin raf ömrünü uzatmak amaciyla modifiye atmosfer teknolojisinde hidrojenin potansiyel uygulamalarını konu alan ilk derlemedir.

Anahtar Kelimeler: İndirgen Atmosfer Kurutma; Gıda Ürünleri; Raf Ömrü; Besinsel Özellikler; Duyusal Özellikler

\footnotetext{
${ }^{1}$ Duried ALWAZEER (Orcid ID: 0000-0002-2291-1628), Igdir University, Faculty of Engineering, Department of Food Engineering, Igdir, Turkey

*Sorumlu Yazar / Corresponding Author: Duried ALWAZEER, e-mail: alwazeerd@gmail.com 


\section{INTRODUCTION}

During the storage period of the foods, some microbiological and enzymatic degradation can take place depending on many intrinsic and extrinsic parameters such as $\mathrm{pH}$, redox, temperature and water activity. These chemical/biochemical deteriorations are able to cause negative effects on the quality attributes of the product such as color, texture, nutritional value (Gorris and Tauscher, 1999; Kader et al., 1989; Saltveit, 2019).

Currently, consumers require to obtain various fruits and vegetables outside of their season; but fresh fruits and vegetables are categorized as highly perishable commodities having short shelf life due to their high moisture content (Karam et al., 2016; Leong and Oey, 2012; Sagar and Suresh Kumar, 2010). To prolong the shelf life of foods and prevent its microbial spoilage and consequently to satisfy the consumer demands of fresh and ready-to-eat products, food processors use generally different types of food additives (Meyer et al., 2002; Rico et al., 2007; Sandhya, 2010). However, since the awareness of consumers to possible hazards of chemical preservatives; technologists and researchers have attempted to introduce new preservative-free techniques to extend the shelf life of fruits and vegetables and make them available out of their season such as modified atmosphere packaging, freezing, cooling and food irradiation (Ihns et al., 2011; Jangam, 2011; Cortellino et al., 2015). In this field, modified atmosphere packaging (MAP) was proposed as an effective method for preserving the sensory and commercial quality of the products and has been widely used in many different foodstuffs such as fruits-vegetables, cereals, meat, seafood, delicatessen, coffee, cheese varieties, ready-to-eat meals (Bevilacqua et al., 2007; Sandhya, 2010; Sanguinetti et al., 2011). MAP is one of the most promotive techniques that is characterized by its low operating costs and diversity of multiuse of its machine and material for packaging different food products. The principle of MAP method is based on replacing the air surrounding the food product inside the package with another gas composition that is suitable for the food nature (Sandhya, 2010). Therefore, the cellular respiration rate, the microbial degradation and the enzyme activities are retarded and then the shelf life of the MAP-packaged foods is extended (Church and Parsons, 1995; Hotchkiss et al., 2006). The effect of MAP on the shelf life of products depends on the type of product, the initial quality and hygiene of the raw material, the composition of gas mixture used for modifying the atmosphere surrounding the food, the storage temperature, the hygiene during processing and packaging, the gas/product volume ratio and the gas permeability of the packaging material (Sivertsvik et al., 2004, 2002). For the best of our knowledge, there is no review in literature concerning the use of hydrogen in modified atmosphere packaging technique for preserving food products.

\section{Characteristics of Gases with potentially uses in RAP Technology}

The main gases generally applied in MAP technique as single or in combination are oxygen $\left(\mathrm{O}_{2}\right)$, carbon dioxide $\left(\mathrm{CO}_{2}\right)$ and nitrogen $\left(\mathrm{N}_{2}\right)$. Recently, there has been an interest in the potential benefits of using noble or 'inert' gases such as argon (Ar). Argon is used for products such as coffee and snack products; but the literature on its application and benefits is restricted. Moreover, it has also been reported the using of other gases such as carbon monoxide (CO), sulphur dioxide $\left(\mathrm{SO}_{2}\right)$, nitric oxide (NO), ozone $\left(\mathrm{O}_{3}\right)$ and chlorine $(\mathrm{Cl})$ in experimental grade (Cortellino et al., 2015; Sandhya, 2010). The use of hydrogen in MAP technique is limited to few research papers as well as some confidential industrial applications and patents ( Cachon et al., 2002).

\section{Oxygen}

Oxygen $\left(\mathrm{O}_{2}\right)$ is a colorless and odorless gas. The presence of $\mathrm{O}_{2}$ in the package affects the 
chemical, biochemical and microbial properties of the product and causes food deterioration; therefore the $\mathrm{O}_{2}$ content in the headspace of packaged foods should be reduced (Farber et al., 1991). Low $\mathrm{O}_{2}$ concentration has an inhibitory effect on the survival of some spoilage microorganisms especially the aerobics but very low levels of $\mathrm{O}_{2}$ can cause fermentation and offflavors in the product after a while (Kays, 1991).

\section{Nitrogen}

Nitrogen $\left(\mathrm{N}_{2}\right)$ is an inert gas and its antimicrobial effect is very low. Although it does not act as a suppressive effect on microorganisms such as carbon dioxide, it can be effective in removing unwanted flavors caused by carbon dioxide. Because of its poorly soluble properties in water and oil, nitrogen prevents package collapse in MAP processing. Although it was reported that the pure nitrogen gas causes drying in some cheese types, the cheese producers in the United Kingdom got good results of cheese packaged with $100 \% \mathrm{~N}_{2}$ gas and used this method widely (Day et al., 1990). The purpose of using nitrogen gas for packaging of cheese under modified atmosphere conditions is to prevent the oxidation, inhibit the development of aerobic microorganisms and provide filling effect inside the package (Farber et al., 1991).

\section{Carbon dioxide}

Carbon dioxide $\left(\mathrm{CO}_{2}\right)$ is a colorless, odorless, non-flammable and non-toxic gas that is both water and oil soluble. Carbon dioxide is the most important gas possessing a direct antimicrobial effect among other gases commonly used in MAP technology. This antimicrobial effect of carbon dioxide originates from its capacity of penetration to the cytoplasm of microbial cell across the cellular wall changing the wall permeability and dissolving in both the cytoplasm and the cellular wall lipid molecules. Another inhibitory effect of carbon dioxide is produced by the formation of carbonic acid due to its dissolution in the aqueous parts of the product; the formed carbonic acid possesses an inhibition property against several microorganisms (Dixon and Kell, 1989). Although carbonic acid causes undesirable sensorial changes in the foodstuff, it reduces the $\mathrm{pH}$ value of the product leading to prevent the development of acid-sensitive microorganisms. In addition, the solubility of carbonic acid used in packaging can vary according to the physical and chemical properties of the packaged food such as water activity, $\mathrm{pH}$, and fat and protein content. On the other hand, it has been reported that increasing the amount of $\mathrm{CO}_{2}$ can cause fading of the color in dairy products and sharp the acidic sour taste in fruits and vegetables (Church and Parsons, 1995; Favati et al., 2007; Maniar et al., 1994). On the other hand, it was reported that Gram-negative bacteria characterized by its richness in lipid component in cellular wall are more sensitive to carbon dioxide than Gram-positive ones. In contrast, anaerobic microorganisms such as $C$. botulinum and $C$. perfringens with lactic acid bacteria; are highly resistant to carbon dioxide (Phillips, 1996). Otherwise, it is reported that $20-40 \% \mathrm{CO}_{2}$ is generally used in MAP technology and the use of fewer levels is unable to prevent the development of microorganisms while the higher levels may cause the package collapse (Dalgaard et al., 1993).

\section{Hydrogen}

In fact the use of hydrogen in the food industry isn't recent and its application is known for a long time in margarine products for example. Hydrogen possesses many special specifications that make it unique and appropriate for specific applications. Hydrogen is the lightest gas (14 times lighter than air), highly flammable, odorless, and burns with a colorless flame (Najjar, 2013). Furthermore, hydrogen is regarded as one of the most promising fuels and the use of hydrogen in various propulsion and energy applications, such as in fuel cells and internal combustion engines is being extensively studied (Tang et al., 2009). The flammability level of hydrogen in the air is between $4 \%$ and $75 \%(\mathrm{v} / \mathrm{v})$ 
and explosion limits in the normal temperature and atmospheric environment are between $18.3 \%$ and 59\% (v/v) (Crowl and Jo, 2007; Najjar, 2013). To avoid the effect of explosion and combustion of hydrogen-containing mixtures the level of hydrogen has to be lower than $4 \%$ where this level is sufficient to achieve the reducing effects of medium/atmosphere (Tang et al., 2009). The authors reported that the presence of nitrogen together with hydrogen decreases the explosion hazards of hydrogen. Tang et al (2009) concluded that the dilution of hydrogen with nitrogen significantly decreases the potential of explosion hazards by decreasing the normalized mass burning rate and the deflagration index.

\section{Reducing Atmosphere packaging (RAP)}

In fact, for the best of our knowledge there is no report concerning the direct use of hydrogen in modified atmosphere packaging technique for preserving food products. The application of hydrogen gas in literature was restricted for the studies concerning its use as a reductant for modifying the oxidoreduction potential (known also as redox potential or ORP) of the medium. So the uses of hydrogen in food preservation techniques are limited to its application as a redox modifier of the medium/product. We can link this application with a potential use of hydrogen as a component of the gaseous atmosphere used in MAP.

The potential application of hydrogen in fruit juices was studied by Alwazeer et al. (2003). The authors proved the advantageous use of hydrogen together with nitrogen $\left(96 \% \mathrm{~N}_{2}\right.$ and $4 \%$ $\mathrm{H}_{2}$ ) for preserving the vitamin $\mathrm{C}$ content and the color of pasteurized orange juice during cold storage (Alwazeer et al., 2003). Another potential field of hydrogen contained- MAP technology is the dairy beverage. A study conducted on a dairy beverage enriched with $2 \%$ linseed and submitted to different degassing process $\left(\mathrm{N}_{2}, \mathrm{~N}_{2} / \mathrm{H}_{2}\right)$ demonstrated the advantageous degassing and packaging process using a gaseous mixture composed from $\mathrm{N}_{2}$ and $\mathrm{H}_{2}$ (Giroux et al., 2008).
This treatment process provides a significant decrease in the oxidative degradation for both unheated and pasteurized dairy beverages permitting preservation effect of colour during storage period.

Method for the packaging of perishable products in a modified atmosphere containing at least $0.1 \%$ volume hydrogen was patented (Remy Cachon et al., 2002). The inventors claimed a method for processing perishable products for prolonged preservation period while ensuring their microbiological safety. They claimed also that hydrogen use could be advantageous to form a protective atmosphere as an additional barrier in the packaging and preservation of perishable foodstuffs and in particular allow to avoid applying a highly acidic $\mathrm{pH}$ to the goods or yet to use additives or preservatives.

The potential application of Reducing Atmosphere Packaging (RAP) for extending the shelf-life of seafood products was assayed in the favour of an industrial company in a confidential study. The results of the microbiological and chemical analyses performed on many types of seafood product packaged by reducing atmosphere packaging as well as the traditional method conducted by keeping the seafood product under ice as a control method showed the advantageous application of the reducing atmosphere packaging for extending the shelf-life of many types of seafood products compared to the traditionally chilled fish products method under ice (personal communication).

A new and alternative packaging technique called Reducing Atmosphere Packaging (RAP) has been developed in the Research Center for Redox Applications in Foods (RCRAF) at Iğdır University (Turkey). This technique is based on the use of a gas mixture $\left(\mathrm{N}_{2}\right.$ and/or $\mathrm{CO}_{2}$ and/or $\mathrm{H}_{2}$ ) containing reducing gas (hydrogen) inside the package of foodstuffs (Figure 1). This reducing gas that constitutes the main theme of this new technique is able to neutralize the oxygen, free radicals and other oxidants found in both the food and the atmosphere surrounding the food 


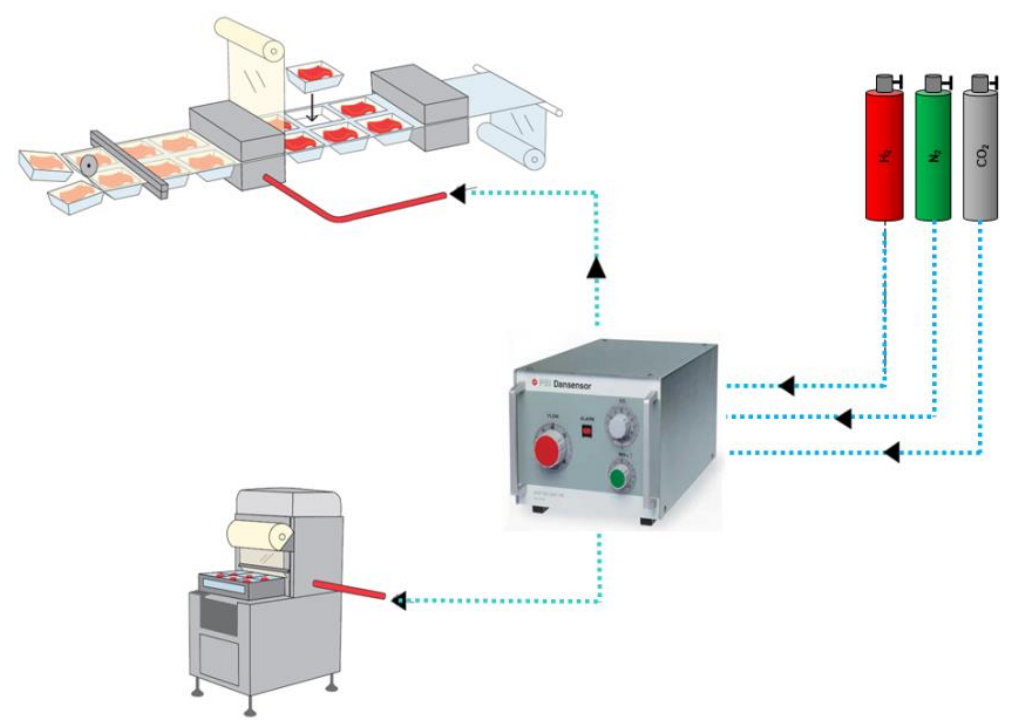

Figure 1. Schematic plan of the Reducing Atmosphere Packaging (RAP) technique

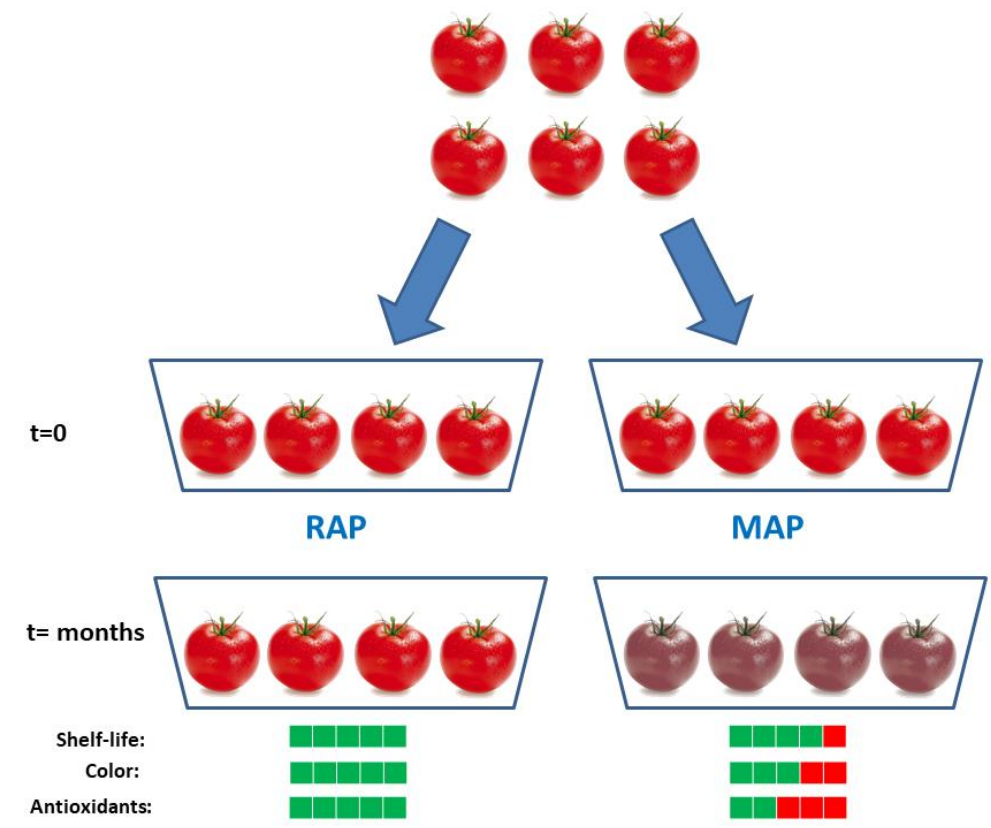

Figure 2. Comparison between reducing atmosphere packaging (RAP) and modified atmosphere packaging (MAP) techniques

Consequently, this reducing atmosphere can minimize the chemical, sensorial and nutritional losses such as color, flavor and vitamins of the packaged food (Figure 2). Different assays conducted in RCRAF using this novel RAP technology on different food products such as strawberry, apricot, sliced potatoes and apples, peppers, grapes and cheeses showed an extended shelf-life of RAP-packaged foods compared with the control samples (unpublished data)

\section{CONCLUSION}

The extension of the shelf life of fresh/processed food product is one of the most serious challenges for food processors. The modified atmosphere packaging technology was proposed as a solution for achieving this goal. The oxidative reactions that could be happened inside 
the food product during storage period leading to negative losses of nutritional, sensorial and economic values of the product limit potential applications of MAP. This limitation of the traditional MAP could be overridden by using the Reducing Atmosphere Packaging technique. This technique offers the opportunity for food producers and processors to enlarge the marketing capacity of product thanks to the extended shelf-life capacity and the freshness notes protection of the foodstuffs.

\section{Conflict of Interest Statement}

The author declares that he has no conflict of interest.

\section{Compliance with Ethical Standards}

This article does not contain any studies with human participants or animals performed by any of the authors.

\section{REFERENCES}

Alwazeer D, Delbeau C, Divies C, Cachon R, 2003. Use of redox potential modificationby gas improves microbial quality, color retention, and ascorbic acid stability of pasteurized orange juice. Int. J. Food Microbiol. 89, 21-29. https://doi.org/http://dx.doi.org/10.1016/S0168 -1605(03)00125-9

Bevilacqua A, Corbo MR, Sinigaglia M, 2007. Combined effects of modified atmosphere packaging and thymol for prolonging the shelf life of caprese salad. J. Food Prot. 70, 722-728.

Cachon R, Divies C, Jeannot P, Prost L, 2002. Method for the packaging of perishable products in a modified atmosphere containing hydrogen and products so made. FR-2811292-A1.

Cachon R, Diviès C, Jeannot P, Prost L., 2002. Procédé pour le conditionnement de produits périssables sous atmosphère modifiée contenant de l'hydrogène et produits ainsi conditionés. WO0202409 (A1).

Church IJ, Parsons AL, 1995. Modified atmosphere packaging technology: a review. J. Sci. Food Agric. 67, 143-152.
Cortellino G, Gobbi S, Bianchi G, Rizzolo A, 2015. Modified atmosphere packaging for shelf life extension of fresh-cut apples. Trends Food Sci. Technol. 46, 320-330.

Crowl DA, Jo Y. Do, 2007. The hazards and risks of hydrogen. J. Loss Prev. Process Ind. 20, 158164. https://doi.org/10.1016/j.jlp.2007.02.002

Dalgaard P, Gram L, Huss HH, 1993. Spoilage and shelf-life of cod fillets packed in vacuum or modified atmospheres. Int. J. Food Microbiol. 19, 283-294.

Day NB, Skura BJ, Powrie WD, 1990. Modified atmosphere packaging of blueberries: microbiological changes. Can. Inst. Food Sci. Technol. J. 23, 59-65.

Dixon NM, Kell DB, 1989. The inhibition by CO2 of the growth and metabolism of microorganisms. J. Appl. Bacteriol. 67, 109-136.

Farber JM, Directorate F, Canada W, 1991. Microbiological Aspects of ModifiedAtmosphere Packaging Technology - A Review $154,58-70$.

Favati F, Galgano F, Pace AM, 2007. Shelf-life evaluation of portioned Provolone cheese packaged in protective atmosphere. LWT-Food Sci. Technol. 40, 480-488.

Giroux HJ, Acteau G, Sabik H, Britten M, 2008. Influence of dissolved gases and heat treatments on the oxidative degradation of polyunsaturated fatty acids enriched dairy beverage. J Agric Food Chem 56, 5710-5716. https://doi.org/10.1021/jf800516x

Gorris LGM, Tauscher B, 1999. Quality and safety aspects of novel minimal processing techniques, in: Processing Foods: Quality Optimization and Process Assessment. CRC Press.

Hotchkiss JH, Werner BG, Lee EYC, 2006. Addition of carbon dioxide to dairy products to improve quality: a comprehensive review. Compr. Rev. food Sci. food Saf. 5, 158-168.

Ihns R, Diamante LM, Savage GP, Vanhanen L, 2011. Effect of temperature on the drying characteristics, colour, antioxidant and betacarotene contents of two apricot varieties. Int. J. Food Sci. Technol. 46, 275-283. https://doi.org/10.1111/j.1365-

2621.2010.02506.x 
Jangam SV, 2011. An Overview of Recent Developments and Some R\&amp;D Challenges Related to Drying of Foods. Dry. Technol. 29, 1343-1357. https://doi.org/10.1080/07373937.2011.59437 8

Kader AA, Zagory D, Kerbel EL, Wang CY, 1989. Modified atmosphere packaging of fruits and vegetables. Crit. Rev. Food Sci. Nutr. 28, 1-30.

Karam MC, Petit J, Zimmer D, Baudelaire Djantou E, Scher J, 2016. Effects of drying and grinding in production of fruit and vegetable powders: A review. J. Food Eng. 188, 32-49. https://doi.org/10.1016/j.jfoodeng.2016.05.001

Kays SJ, 1991. Postharvest physiology and handling of perishable plant products. Van Nostrand Reinhold Inc.

Leong SY, Oey I, 2012. Effects of processing on anthocyanins, carotenoids and vitamin $\mathrm{C}$ in summer fruits and vegetables. Food Chem. 133, 1577-1587. https://doi.org/10.1016/j.foodchem.2012.02.05 2

Maniar AB, Marcy J.E, Bishop JR, Duncan SE, 1994. Modified atmosphere packaging to maintain direct-set cottage cheese quality. J. Food Sci. 59, 1305-1308.

Meyer AS, Suhr KI, Nielsen P, Holm F, 2002. Natural food preservatives. Minimal Process. Technol. food Ind. 124-174.

Najjar YSH, 2013. Hydrogen safety: The road toward green technology. Int. J. Hydrogen Energy 38, 10716-10728. https://doi.org/10.1016/j.ijhydene.2013.05.126

Phillips CA, 1996. Modified atmosphere packaging and its effects on the microbiological quality and safety of produce. Int. J. Food Sci. Technol. 31, 463-479.
Rico D, Martin-Diana AB, Barat JM, Barry-Ryan C, 2007. Extending and measuring the quality of fresh-cut fruit and vegetables: a review. Trends Food Sci. Technol. 18, 373-386.

Sagar VR, Suresh Kumar P, 2010. Recent advances in drying and rehydration of fruits and vegetables: a review. J. Food Sci. Technol. 47, 15.

Saltveit ME, 2019. Respiratory metabolism, in: Postharvest Physiology and Biochemistry of Fruits and Vegetables. Elsevier, pp. 73-91.

Sandhya, 2010. Modified atmosphere packaging of fresh produce: Current status and future needs. LWT - Food Sci. Technol. 43, 381-392. https://doi.org/https://doi.org/10.1016/j.1wt.200 9.05.018

Sanguinetti AM, Del Caro A, Mangia NP, Secchi N, Catzeddu P, Piga A, 2011. Quality changes of fresh filled pasta during storage: Influence of modified atmosphere packaging on microbial growth and sensory properties. Food Sci. Technol. Int. 17, 23-29.

Sivertsvik M, Jeksrud WK, Rosnes JT, 2002. Review A review of modified atmosphere packaging of fish and fishery products - significance of microbial growth, activities and safety 107127.

Sivertsvik M, Jeksrud WK, Vågane Å, Rosnes JT, 2004. Solubility and absorption rate of carbon dioxide into non-respiring foods: Part 1: Development and validation of experimental apparatus using a manometric method. J. Food Eng. 61, 449-458.

Tang C, Huang Z, Jin C, He J, Wang J, Wang X, Miao $\mathrm{H}, 2009$. Explosion characteristics of hydrogennitrogen-air mixtures at elevated pressures and temperatures. Int. J. Hydrogen Energy 34, 554561.

https://doi.org/10.1016/j.jhydene.2008.10.028 